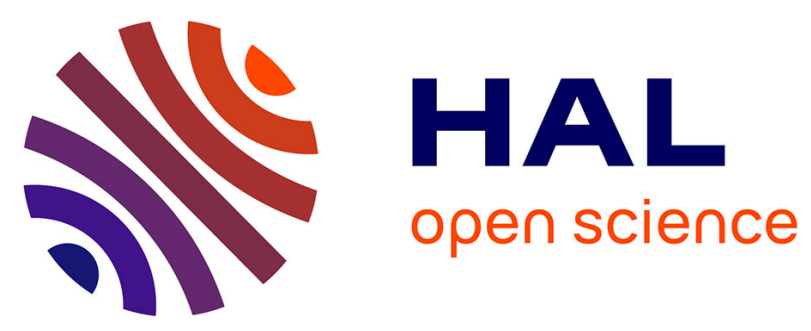

\title{
Iron supply pathways between the surface and subsurface waters of the Southern Ocean: From winter entrainment to summer storms
}

Sarah Nicholson, Marina Lévy, Julien Jouanno, Xavier Capet, Sebastiaan Swart, Pedro M. S. Monteiro

\section{To cite this version:}

Sarah Nicholson, Marina Lévy, Julien Jouanno, Xavier Capet, Sebastiaan Swart, et al.. Iron supply pathways between the surface and subsurface waters of the Southern Ocean: From winter entrainment to summer storms. Geophysical Research Letters, 2019, 46 (24), pp.14567-14575. 10.1029/2019GL084657 . hal-02422875

\section{HAL Id: hal-02422875 \\ https://hal.science/hal-02422875}

Submitted on 2 Dec 2020

HAL is a multi-disciplinary open access archive for the deposit and dissemination of scientific research documents, whether they are published or not. The documents may come from teaching and research institutions in France or abroad, or from public or private research centers.
L'archive ouverte pluridisciplinaire HAL, est destinée au dépôt et à la diffusion de documents scientifiques de niveau recherche, publiés ou non, émanant des établissements d'enseignement et de recherche français ou étrangers, des laboratoires publics ou privés. 
1 Iron supply pathways between the surface and subsurface waters of the Southern 2 Ocean: from winter entrainment to summer storms

3

4 S.-A. Nicholson ${ }^{1}$, M. Lévy ${ }^{2}$, J. Jouanno ${ }^{3},{\text { X } \text { Capet }^{2} \text {, S. Swart }}^{4,5}$ and P.M.S Monteiro ${ }^{1}$

$5 \quad{ }^{1}$ Southern Ocean Carbon-Climate Observatory (SOCCO), CSIR, Cape Town, South Africa

$6 \quad{ }^{2}$ Sorbonne Université, LOCEAN-IPSL, CNRS-IRD-MNHN, Paris, France

$7 \quad{ }^{3}$ LEGOS, Université de Toulouse, IRD, CNRS, CNES, UPS, Toulouse, France.

$8{ }^{4}$ Department of Marine Sciences, University of Gothenburg, Gothenburg, Sweden

$9 \quad{ }^{5}$ Department of Oceanography, University of Cape Town, Rondebosch, South Africa 10

11 Corresponding author: Sarah-Anne Nicholson, snicholson@csir.co.za

12

- Eddy advection and winter mixing support annual surface iron supplies in equal proportion in an eddy resolving model.

- Eddy advection contributes $25 \%$ to restocking subsurface iron reservoir in addition to $75 \%$ by local recycling.

- Storms are the most efficient in increasing iron supplies in early summer and over ocean fronts. 


\section{Abstract}

Dissolved iron (DFe) plays an immeasurable role in shaping the biogeochemical processes of the open-ocean Southern Ocean. However, due to observational constraints iron supply pathways remain poorly understood. Using an idealized eddy-resolving physical-biogeochemical model representing a turbulent sector of the Southern Ocean with seasonal buoyancy forcing and zonal winds overlaid by storms, we quantify the importance of a range of subsurface and surface iron supply mechanisms. The main physical supply pathways to the surface layer are via eddy advection and winter convective mixing in equal proportions. The associated subsurface loss of DFe is restocked via net remineralisation (75\%) and eddy advection $(25 \%)$. Summer storms resulted in weak DFe supplies relative to the seasonal supplies $(<7.6 \%)$. However, in situations of deep summer mixed-layers and when interacting with underlying ocean fronts, summer storms resulted in enhanced diffusive and advective DFe supplies and raised summer primary production by $20 \%$ for several days.

\section{Plain Language Summary}

The surface of the Southern Ocean is iron depleted, which strongly limits the amount of phytoplankton growth that can occur. Every year, deep mixing in winter moves large quantities of iron from a subsurface under-utilized iron reservoir to the surface alleviating the iron limitation. Once there is sufficient light in spring, phytoplankton consume this iron supply leaving the summer months iron depleted. How exactly phytoplankton are supported through the summer when iron limitations are strong remains under question. This study uses a numerical model to simulate the seasonal and intraseasonal iron supply pathways. We show that physical supplies via advection by eddies and winter mixing drive surface seasonal supplies in equal proportions. During summer, storms supply iron via intermittent mixing and thus increase primary production, particularly over regions of strong ocean fronts.

\section{Introduction}

Dissolved iron (DFe) limits phytoplankton growth across the surface of the Southern Ocean (SO), particularly in the open-ocean regions far from terrestrial DFe supplies (Boyd and Ellwood, 2010; Moore et al., 2013). Analysis of a compilation of open-ocean DFe data has suggested that the limitation is alleviated on an annual basis by a 'once-off' basin-wide supply during winter driven by deep convective mixing, which entrains large volumes of iron-laden subsurface waters to the surface (Tagliabue et al., 2014). During spring, when light availability increases, the winter supply is consumed by the development of widespread phytoplankton blooms, such as occurring in the sub-Antarctic zone (SAZ, Thomalla et al. 2011 and Racault et al. 2012). During summer, physical iron supplies (i.e., via diapycnal mixing and advection) between the subsurface and surface ocean have been estimated to be negligible in comparison to winter entrainment (Tagliabue et al., 2014) and rapid iron biological recycling is thought to extend the spring phytoplankton production through the summer months (Boyd et al., 2005; Tagliabue et al., 2014; Boyd et al., 2017).

In addition to the 'once-off' seasonal supply, there is increasing observational evidence from satellites (Fauchereau et al., 2011; Thomalla et al., 2011; Carranza and Gille, 2015) and from insitu high-resolution gliders (Swart et al., 2015; Mtshali et al., 2019) that storms could be entraining intermittent DFe supplies that could support phytoplankton production, especially in summer when DFe limitations are strongest (Boyd, 2002; Ryan-Keogh et al., 2018; Mtshali et al., 2019). 
Carranza and Gille (2015) found strong positive correlations between high wind-speeds with enhanced surface chlorophyll in summer and concluded that local storm-driven entrainment was the dominant nutrient supply mechanism over advection by Ekman pumping. Further, Swart et al. (2015) linked sustained summer chlorophyll in the SAZ to wind-driven mixed-layer depth (MLD) variability on synoptic timescales. The role of storm-driven mixing in supporting SAZ summer production was explored in a one-dimensional modelling study by Nicholson et al. (2016), which showed that intermittent mixing events could entrain subsurface DFe, provided there was a subsurface post-storm resupply mechanism.

Many theoretical studies have investigated in detail the importance of wind in increasing the supply of nutrients to the subsurface and the surface ocean, particularly when the wind interacts with different meso and submesoscale features (fronts and eddies, e.g., Mahadevan and Tandon, 2006; Lévy et al., 2009; Whitt et al., 2017a, 2017b). These studies have focused on particular localized scenarios and their relevance has not yet been contextualized within the broader seasonal mean state. The SO, in particular the SAZ, is a region of strong eddy (Frenger et al., 2015) and small-scale frontal activity (du Plessis et al., 2017, 2019); and strong winds from passing storms (Yuan, 2004; Patoux et al., 2009; Yuan et al., 2009). We hypothesize that storms increase mixing and advection during summer that are enhanced by wind-mesoscale interactions and may result in non-negligible physical iron supplies from the subsurface to the surface ocean to support phytoplankton production beyond what is possible by the once-off winter supply.

We aim to address the following, from a seasonal-scale perspective: What are the dominant supply mechanisms of dissolved iron over the seasonal cycle? What maintains the sub-surface iron reservoir? From an intraseasonal-scale perspective: How is iron supplied and utilized in response to summer storms? We address these questions using an idealized eddy-resolving biogeochemical model of the SO, forced by winds and climatological heat fluxes (seasonal forcing) and by a series of passing storms (intraseasonal).

\section{Model setup and design}

\subsection{Physical Model}

The model architecture was provided by the Nucleus for European Modeling of the Ocean (NEMO, Madec, 2008). The domain, zonal and meridional extent of $\mathrm{L}_{\mathrm{x}}=2000 \mathrm{~km}$ and $\mathrm{L}_{\mathrm{y}}=3000$ $\mathrm{km}$ respectively (representing $40-70^{\circ} \mathrm{S}$ ) and vertical extent of $4000 \mathrm{~m}$, was setup on a $\beta$-plane with $\mathrm{f}_{0}=-1 \times 10^{-4} \mathrm{~s}^{-1}$ and $\beta=1 \times 10^{-11} \mathrm{~m}^{-1} \mathrm{~s}^{-1}$ at the center. A linear equation of state dependent on temperature is used with a thermal expansion $\alpha=2 \times 10^{-10} \mathrm{~K}^{-1}$. The eastern and western boundaries were periodic, while the northern and southern were restricted. The northern boundary temperature was restored to an exponential profile to allow deep residual overturning (Abernathey et al., 2011) and varied seasonally in the upper $150 \mathrm{~m}$ to mimic observed seasonal variability at $40^{\circ} \mathrm{S}$ (Jouanno et al., 2016). Random bathymetry (Figure S1) with linear bottom friction was used to limit the zonal volume transport (Rintoul et al., 2001). In the vertical, 50 levels were used, with 10 levels of $10 \mathrm{~m}$ thickness in the upper $100 \mathrm{~m}$, increasing exponentially in thickness to $172 \mathrm{~m}$ at the bottom. For vertical mixing we used a Generic Length Scale scheme with a k- $\boldsymbol{\varepsilon}$ closure (Reffray et al., 2015), and for tracer and momentum advection, a 3rd order upstream biased scheme and no additional explicit diffusion. Refer to Jouanno et al. (2016) for further description of the 
configuration, including rationale for the choice of bathymetry, restoring, mixing and advection schemes.

The configuration was initialized using a hierarchy of increasing horizontal resolution starting from $100 \mathrm{~km}$, initialized from rest and adjusted for 200 years. This initialized a $24 \mathrm{~km}$ resolution run, which spun-up for 400 years, from which a $5 \mathrm{~km}$ run was initialized (then adjusted for 30 years). Our analysis is based on the mesoscale resolving $5 \mathrm{~km}$ run. Outputs are saved as two-day means and the last five years of model integration are analyzed. The analysis is restricted to a northern band $(\mathrm{x}=2000-2800 \mathrm{~km})$ of the domain, which is representative of SAZ like conditions (Figure S1) and not influenced by boundary conditions.

\subsection{Seasonal and storm surface forcing}

The surface boundary was forced mechanically by wind and thermodynamically by heat fluxes. The heat fluxes varied seasonally and zonally and were constructed from OAFlux data between 1984 - 2007 (Yu and Weller 2007 and Jouanno et al. 2016). Background wind stress $\left(\boldsymbol{\tau}_{\boldsymbol{b}}\right)$ is uniform in time and varies zonally as:

$\tau_{b=} \tau_{0} \sin \frac{\pi y}{L_{y}}$

where, $\tau_{0}=0.15 \mathrm{Nm}^{-2}$.

SO mid-latitude storms are large cyclonic features (diameter of $900 \mathrm{~km}$, Figure S2), which were represented here as cyclonic anomalies of varying magnitudes in the background wind stress field and were created using a Rankine vortex model (described in Jouanno et al. 2016). The direct effect of storms on heat flux is not accounted for. Storm characteristics (i.e., duration and magnitude) have been designed based on statistics for the SO (Patoux et al., 2009). The simulated storms are unique, they have different magnitudes, locations across the domain, and times in each year. They have periods of approximately 10 days and traverse zonally across the domain in two days, i.e., the time interval during which their associated winds reach maximum intensity (linear intensification and decay occur over periods of 1 day each). A total of 16 summer storms passed over the region analyzed over 4 consecutive summers (Figure S2). Storms are stronger in intensity during winter months than in summer, as observed to occur by Yuan et al. (2009), thus the storm wind stress max $\left(\boldsymbol{\tau}_{\boldsymbol{m a x}}\right)$ is modulated by a seasonal cycle where it varies from $\boldsymbol{\tau}_{\boldsymbol{m a x}}=\mathbf{1 . 5} \mathbf{~ N m}^{-\mathbf{2}}$ in winter to $\frac{\boldsymbol{\tau}_{\max }}{2}$ in summer. This seasonal storm intensity, together with background wind and heat flux, resulted in the seasonality of the MLD, which deepened in response to convective cooling and stronger storms in winter to a mean of $\sim 175 \mathrm{~m}$ and shoaled to a mean of $\sim 30 \mathrm{~m}$ in summer due to strong buoyancy forcing via surface heating (in agreement with SAZ MLD ranges in du Plessis et al. 2019).

\subsection{Biogeochemical Model}

The biogeochemical model Pelagic Interaction Scheme for Carbon and Ecosystems (PISCES, Aumont et al. 2015), a well-tested and constrained model, simulates the cycle of DFe, phosphorous, nitrogen, and silicate. PISCES was coupled online to the dynamical configuration described above. DFe has been initialized based on lower ranges for the $\mathrm{SO}$, which is more representative of open-ocean waters (Tagliabue et al., 2012). We set DFe to $0.05 \mathrm{nmol} \mathrm{L}^{-1}$ in the 
surface increasing linearly to $0.5 \mathrm{nmol} \mathrm{L}{ }^{-1}$ until $500 \mathrm{~m}$ depth (Figure S3), after which DFe is kept constant. For simplicity, we chose to force the model with high (by two factors) nitrate, phosphate and silicate, such that the two limitations on phytoplankton are light and iron. While silicate limitation occurs in the SO (Boyd et al. 2002), these broadly repleted macronutrient are typical of SO surface waters, especially in the SAZ (Giddy et al., 2012), and are therefore not the primary limitation. Nutrient profiles are restored at their northern boundary to the initial profile. The Monotonic Upstream centered Scheme for Conservation Laws (MUSCL) in flux-form is used for the advective transport of biogeochemical tracers (Lévy et al., 2001).

\section{Results}

Here we first show the model ability to simulate seasonal and intraseasonal responses of surface phytoplankton, then the seasonal and intraseasonal (summer storms) pathways of DFe are investigated.

\section{1 Surface chlorophyll}

The seasonal surface chlorophyll (chl $l_{\text {surf }}$ ) shows a spring bloom peaking to $\sim 0.5 \mathrm{mg} \mathrm{m}^{-3}$ during September and a constant mean of $\sim 0.2 \mathrm{mg} \mathrm{m}^{-3}$ in summer (Figure 1a). This range is comparable with open-ocean SO chlorophyll (Thomalla et al., 2011). There are raised intraseasonal peaks of

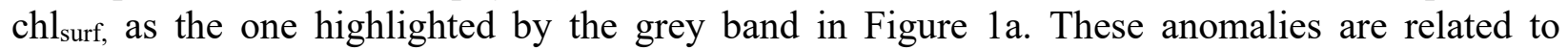
increased windspeed anomalies associated with the prescribed storms (Figure 1b). The strongest correlations occurred 0 - 2 days after the storm passage, consistent with Carranza and Gille (2015). For illustration, chl $1_{\text {surf }}$ patterns are shown in Figure 1c-e before, during and after a passing storm in November. Pre-storm, chl surf was low and spatially heterogeneous, with the highest concentrations occurring within mesoscale fronts while background concentrations were low $(<$ $\left.0.15 \mathrm{mg} \mathrm{m}^{-3}\right)$. The storm-driven enhancements of $\mathrm{chl}_{\text {surf }}$ is evident both in the frontal features and in the background concentrations (mean increase of 12\%, Figure 1d, S4). However, the strongest increase of $\mathrm{chl}_{\text {surf }}(52 \%)$ occurs in frontal features, particularly evident in the post-storm stage.

\section{2 The seasonal dissolved iron budget}

To investigate the pathways of DFe, the supplies were averaged spatially and separated into contributions driven by physical and biological processes. The physical contributions were separated into vertical diffusion and total advection (the sum of lateral and vertical components, Figure 2a-d). The total biological contribution to the DFe budget includes DFe uptake by phytoplankton and supply by net remineralization. Net remineralization includes disaggregation of small particulate iron; zooplankton excretion and sloppy feeding; coagulation and aggregation of particulate iron; and scavenging.

In the euphotic layer (set constant defined by maximum depth of production), the signature of the "once-off" winter DFe supply is seen as a gain of vertical diffusive DFe during winter (July September) (Figure 2c). This corresponds to diffusive entrainment associated with mixed-layer deepening (Figure 2e). A cumulative supply (averaged spatially and summed temporally) of 4.3 $\mu \mathrm{mol} \mathrm{DFe} \mathrm{m}^{2} \mathrm{yr}^{-1}$ was brought to the surface due to deep winter mixing, which is in the lower range estimated by Tagliabue et al. 2014. In winter the total advective supply of DFe has a lower magnitude with respect to mixing (Figure S5). However, it is larger in spring and early summer 
182 (October - December). The total annual cumulative supply of this advective flux was $4.5 \mu$ mol $\mathrm{DFe} \mathrm{m}^{2} \mathrm{yr}^{-1}$, thus has a comparable magnitude to the "once-off" winter supply. Together, advection and diffusion maintain a positive DFe tendency during winter. The advective flux can be explained by increased eddy advection (Figure 2a-d), during winter, spring and early summer which dominates the vertical flux (Figure 2f). This increase in the advective flux is not present in a lower resolution run (Figure S6), where mesoscale eddies are not resolved.

Euphotic layer primary production ( $\mathrm{PP}_{\text {eup }}$ ) increases from June (Figure 2c). After winter, when the MLD shoals (Figure 2e), a spring bloom is present peaking between September and October, which rapidly decreases DFe. However, even during summer months elevated $\mathrm{PP}_{\text {eup }}$ is maintained (Figure 2c). The seasonal range of $\mathrm{PP}_{\text {eup }}$ (converted to carbon: $200-400 \mathrm{mg} \mathrm{C} \mathrm{m}^{-2} \mathrm{~d}^{-1}$ ) falls within open-ocean estimates (Arrigo et al., 2008). After the spring bloom, when the MLD remains shallow $(\sim 30 \mathrm{~m})$, most of the summer $\mathrm{PP}_{\text {eup }}$ is sustained by the net remineralized supply (cumulative of $33 \mu \mathrm{mol} \mathrm{DFe} \mathrm{m}^{2} \mathrm{yr}^{-1}$ ), particularly in the late summer period when $\mathrm{PP}_{\text {eup }}$ and net remineralization are tightly coupled (Figure $2 \mathrm{c}$ ).

In the subsurface (Figure $2 \mathrm{~d}$ ), there is a cumulative loss of DFe primarily due to winter entrainment (-4 $\left.\mu \mathrm{mol} \mathrm{DFe} \mathrm{m}^{2} \mathrm{yr}^{-1}\right)$, restocked by eddy-driven advection $\left(1 \mu \mathrm{mol} \mathrm{DFe} \mathrm{m}^{2} \mathrm{yr}^{-1}\right)$ and remineralization $\left(3.4 \mu \mathrm{mol} \mathrm{DFe} \mathrm{m}^{2} \mathrm{yr}^{-1}\right)$. Note the weak subsurface production in October $(-0.4$ $\left.\mu \mathrm{mol} \mathrm{DFe} \mathrm{m}^{2} \mathrm{yr}^{-1}\right)$. Net remineralization, although lower than in the euphotic layer, continuously supplies the subsurface reservoir, particularly during winter to spring (Figure 2d). While advection contributes to restocking the subsurface between November to February.

203

204

205

206

207

208

209

210

211

212

213

214

215

216

217

218

219

220

221

222

223

\subsection{Impact of summer storms}

Figure $3 \mathrm{a}$ and $\mathrm{b}$ show the spatially averaged storm-driven change of chl $1_{\text {surf, }} \mathrm{PP}_{\text {eup }}$ and MLD for 16 unique summer storms (Figure S2). The change is computed from the time-step at the peak of the storm and the time-step before the storm $\left(\Delta:\right.$ storm-pre storm). Both $\Delta \mathrm{chl}_{\text {surf }}$ and $\Delta \mathrm{PP}$ eup are strongly positively correlated to $\triangle \mathrm{MLD}(\mathrm{r}=0.808$ and $\mathrm{r}=0.801$ respectively). In other words, the stronger storm-driven deepening of the MLD the larger the response in $\Delta \operatorname{chl}_{\text {surf }}$ and $\triangle \mathrm{PP}$ eup. During early summer, storms drive the largest change in $\triangle \mathrm{MLD}(>10 \mathrm{~m})$ and thus of $\triangle \mathrm{PP}_{\text {eup}}$,

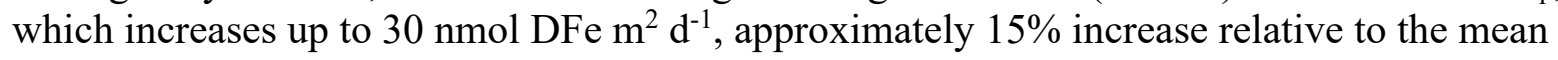
summer range of $\mathrm{PP}_{\text {eup }}$ (Figure $3 \mathrm{~b}$ ). In late summer, both mean storm-driven $\triangle \mathrm{PP}_{\text {eup }}$ and $\triangle \mathrm{MLD}$ are negligible.

Next, we quantify how much of the increase in $\triangle \mathrm{PP}_{\text {eup }}$ in response to storms is in strong fronts (horizontal gradients in sea surface temperature $>65^{\text {th }}$ percentile), versus weak/no fronts (Figure $3 \mathrm{c})$. For 14 summer storms, the mean response of $\Delta \mathrm{PP}_{\text {eup }}$ in fronts compared to weak/no fronts is the same $(r=0.98)$, particularly for late summer storms. However, $\Delta \mathrm{PP}_{\text {eup }}$ is skewed toward larger values in frontal areas, even for weak $\Delta \mathrm{PP}_{\text {eup }}$ and there are a few cases in early summer where $\triangle \mathrm{PP}_{\text {eup }}$ is larger in fronts, up to a factor of two. These cases had deeper pre-storm MLD's and stronger winds.

Figure 4 focuses on the storm for which there is a doubling of $\Delta \mathrm{PP}_{\text {eup }}$ at fronts (Figure $3 \mathrm{c}$ ). The storm occurred between the $16-18^{\text {th }}$ of November marked in Figure 1a and c, d). The response of $\mathrm{PP}_{\text {eup }}$ is maximum a few days after the storm $\left(\sim 22^{\text {nd }}\right)$ and stronger in fronts. During the storm, diffusive entrainment is the dominant DFe supplier to the top $50 \mathrm{~m}$, coinciding with a deepening of the MLD and the active mixing extent (Figure $4 \mathrm{c}, \mathrm{f})$. The diffusive supply is stronger (42\%) 
in fronts (e.g., $300 \mathrm{nmol} \mathrm{DFe} \mathrm{m}^{3} \mathrm{~d}^{-1}$ compared to $172 \mathrm{nmol} \mathrm{DFe} \mathrm{m}^{3} \mathrm{~d}^{-1}$ in no fronts). Advection resupplies some of the entrained DFe beneath the MLD during the storm (Figure $4 \mathrm{~b}, \mathrm{c}$ ) and is also stronger in fronts (e.g., $105 \mathrm{nmol} \mathrm{DFe} \mathrm{m}^{2} \mathrm{~d}^{-1}$ compared to $51 \mathrm{nmol} \mathrm{DFe} \mathrm{m}^{2} \mathrm{~d}^{-1}$ in weak/no fronts). The enhanced advection in both scenarios is due to Ekman pumping (accounting for 50\% increase in mean total vertical advection, Figure S7), while the remainder is due to the rectified effect of mesoscale-wind interactions.

\section{Discussion and conclusion}

This study investigates the dissolved iron budget in the open waters of the SAZ with an idealized eddy-resolving biogeochemical model, intermittently disturbed by storms to investigate seasonal and intraseasonal supply pathways.

On the seasonal-scale, in addition to the "once-off" winter DFe supply to the surface by convective mixing (Tagliabue et al., 2014), this study shows that enhanced eddy activity contributes to a DFe supply of similar magnitude over the year (Figure 2c) and is thus an important supply mechanism for SO productivity (supporting 14\% annual and 25\% spring-summer production). Our estimate of the eddy DFe flux is likely underestimated as the horizontal resolution used $\left(\sim 5 \mathrm{~km}\right.$ or $\left.1 / 24^{\circ}\right)$ is not sufficient to represent submesoscale iron fluxes (Rosso et al., 2016; Takaya et al., 2019).

Iron supplies to the euphotic layer can only be maintained if the subsurface iron reservoir is being refilled. In the subsurface, we showed that the dominant seasonal supplies were via net remineralization (July to October), a result of detrainment of euphotic bioavailable iron during winter, and via total advection driven by seasonally increased eddy advection (November to February) (Figure 2d). No previous studies have contrasted the role of these different subsurface pathways. However, individual studies have shown that remineralization (Boyd et al., 2017), upwelling (Rosso et al., 2016) and lateral advection (Bowie et al., 2009) are important. The impact of remote advection was excluded here but has been shown to be important (Graham et al., 2015), as have hydrothermal vents (Tagliabue et al., 2010; Ardyna et al., 2019) and aeolian dust (Jickells et al., 2005).

On the intraseasonal-scale, we investigated whether summer storms could supply iron to support summer production above and beyond these seasonal iron supplies. Storm-driven supplies are currently unresolved by temporal coverage of available DFe observations (Mtshali et al., 2019). In agreement with Fauchereau et al. (2011) and Carranza and Gille (2015), we found strong positive correlations between storm-driven anomalies of the MLD with surface chlorophyll, but also with primary production (Figure 3a,b). Moreover, we showed that the magnitude of these anomalies is dependent on the timing of the summer storm. Early summer storms had the largest mean impact $(20 \mathrm{~m})$ on the MLD and thus on primary production. During this period, the largest increase in production (40 nmol DFe $\mathrm{m}^{2} \mathrm{~d}^{-1}$ ) resulted from storm-front interactions. Fronts amplified the storm-driven iron supplies primarily via enhanced diffusive entrainment associated with deeper mixing and enhanced advection below the MLD. Furthermore, the storm-driven mixing contribution of DFe is larger than the advective contribution, so Ekman pumping, and more generally enhanced advection, is of second order compared to mixing (Figure 4). While these results support a well-established hypothesis that winds interacting with fronts enhance mixing (Lévy et al., 2009; Whitt et al., 2017a) and advection (Franks and Walstaad, 1997; Lévy et al., 
2009; Whitt et al., 2017b), when contrasted against the seasonal-scale perspective, it results in at most a $20 \%$ increase of PP for several days. Towards late summer, storm-frontal interactions were inhibited by strong heat flux and weaker winds that maintained shallow MLDs, limiting both entrainment of iron and the development of instabilities (Capet et al., 2008; Sasaki et al., 2014; Callies et al., 2015; Lévy et al., 2018; du Plessis et al., 2019).

Our approach is based on a simplified model in which some connected and potentially relevant processes have not been accounted for and may result in the underestimation of storm impacts. The first simplification concerns the representation of the storms, which only includes an anomaly in the wind stress. However, surface heat loss has been shown to be important: Carranza and Gille (2015) showed that SO summer MLD variance was explained by windspeed $(21.8 \%)$ and net surface heat flux (16.7\%). This unaccounted thermodynamic effect may further destabilize the MLD during a storm, and potentially increase the storm-driven DFe supply during late summer when buoyancy forcing is strong. The two storms that stand out in Figure $3 \mathrm{c}$ are likely most representative of reality because they are associated with mixed-layer anomalies that are comparable to the magnitude observed in the SO (i.e., summer SAZ MLD standard deviations of $16 \mathrm{~m}$, Swart et al., 2015). The model horizontal resolution (not submesoscale-resolving) could potentially underestimate the effect of storms. Increasing the horizontal resolution could lead to stronger and deeper responses in vertical advection and diffusion and it might also impact the deep iron reservoir. Since Jouanno et al. 2016 demonstrated full-depth impacts of a storm on dissipation and advection. The quantitative results in our model should be considered the lower range of potential impacts of storms on DFe supply.

The idealized nature of our simulation has not allowed us to explore the full range of situations that are representative of the SO. For instance, the timing of our bloom is too early compared to some observations (e.g. Swart et al. 2015). These findings give new insight on the response of biophysical processes to storm events. Given the potential susceptibility of SO iron supplies and primary production to future changes in storm seasonality and characteristics, future work should investigate the regional-scale sensitivity of storm-driven iron supplies by testing a wider range of SO mixing seasonal cycles (e.g., Llort et al., 2016; 2019), which could affect the bloom timing, mean seasonal supplies and the significance of storms.

\section{Acknowledgments}

Authors thank Christian Ethé for technical assistance. This work was supported by: CSIR Parliamentary Grant, NRF-SANAP grants SNA170522231782 and SNA170524232726, the Young Researchers Establishment Fund (YREF 2019 0000007361), research staff exchange SOCCLI program (FP7-PEOPLE-2012-IRSES). M. L acknowledges the CNES (climcolor project), ANR (SOBUMS project, ANR-16-CE01-0014)) and SS the Wallenberg Academy Fellowship (WAF 2015.0186). Data available at ftp://socco.chpc.ac.za/Nicholson_etal2019/ 
Figures:

313

(a) Seasonal mean

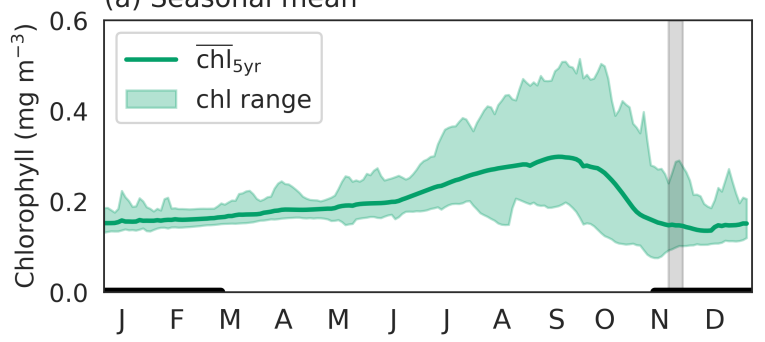

(b) Summer windspeed and chlorophyll anomalies

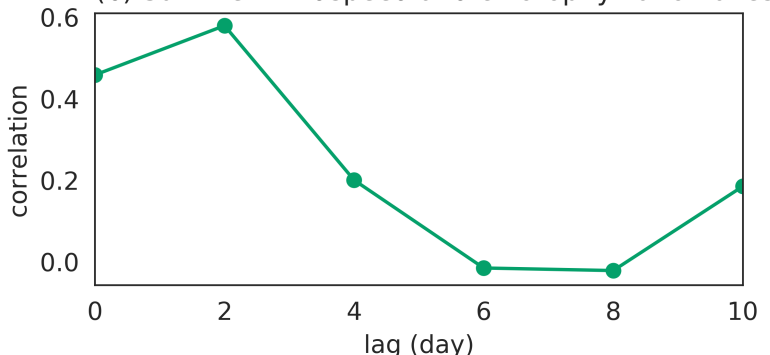

lag (day)

(c) Pre-storm (12-14 Nov)

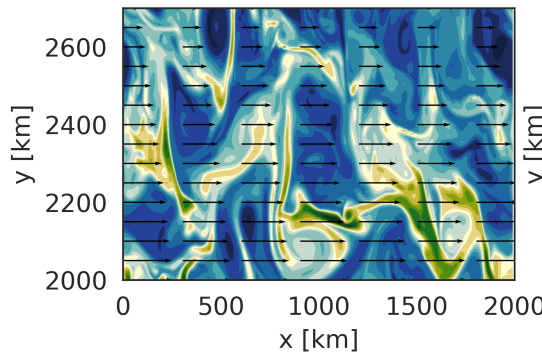

(d) Storm (16-18 Nov)

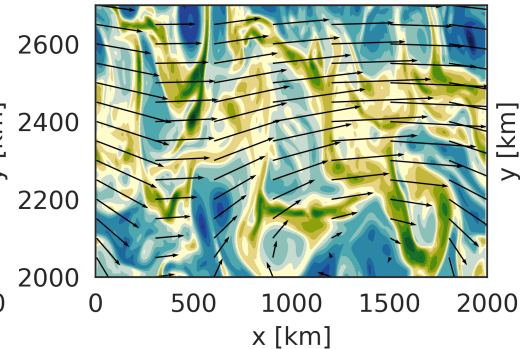

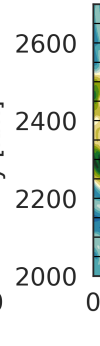
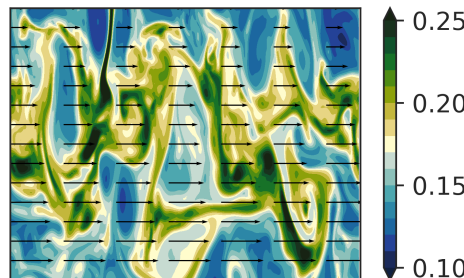

$500 \quad 1000 \quad 1500 \quad 2000$ $\mathrm{x}[\mathrm{km}]$

$-0.15$

Figure 1: a) Seasonal mean of surface chlorophyll $\left(\mathrm{mg} \mathrm{m}^{-3}\right)$, with green shading for the range (min - max), (b) cross-correlation between summer (01 November - 01 March) intraseasonal anomalies in windspeed (16 individual storms) and in surface chlorophyll, and (c-e) the response of two-day mean surface chlorophyll to a single and unique storm occurring in one summer as marked by gray shading in (a). Black vectors in c-e are wind stress. 

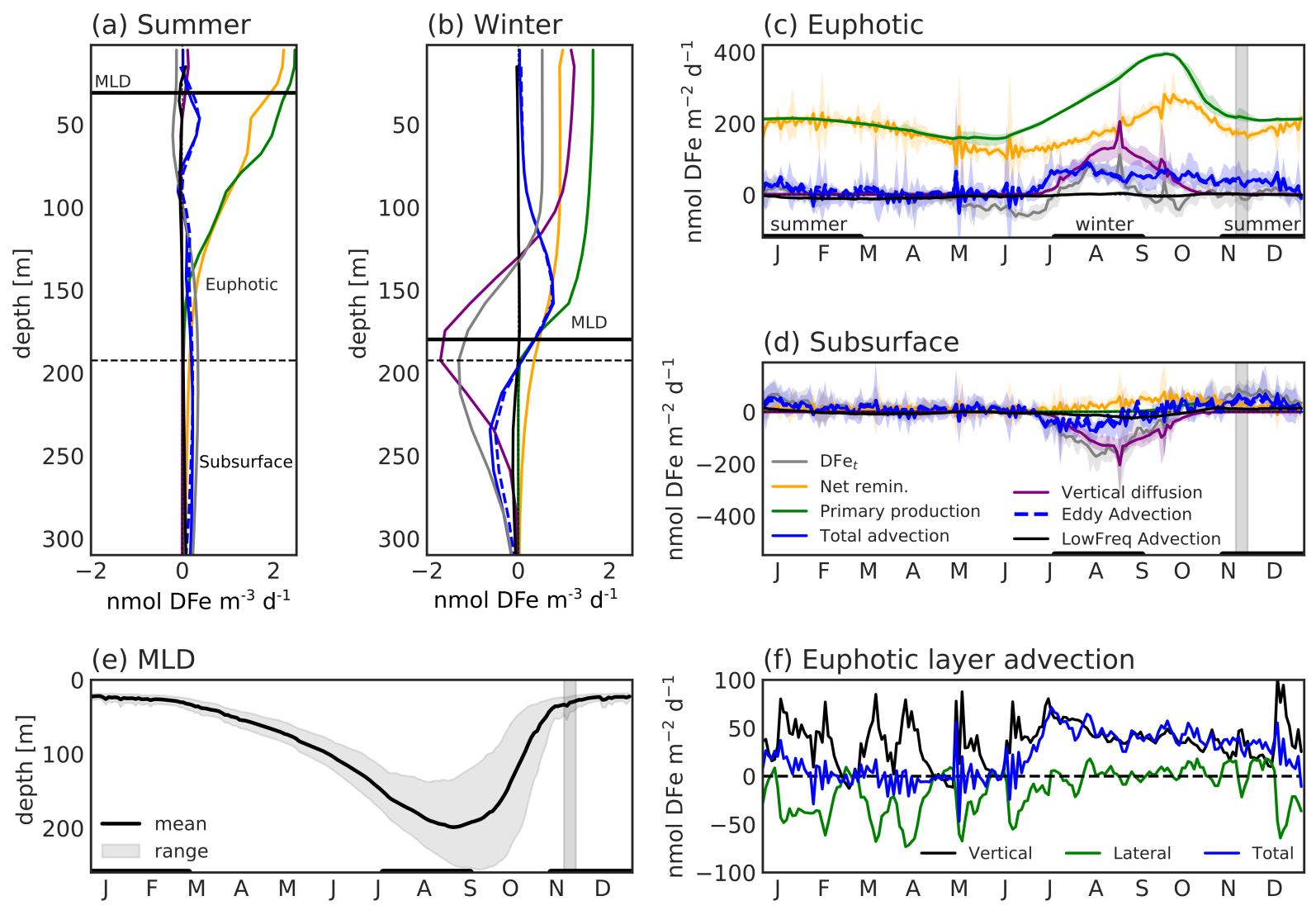

324 Figure 2: The seasonal climatology of the dissolved iron (DFe) budget computed over 5 years and averaged spatially. The iron budget terms (nmol DFe $\mathrm{m}^{3} \mathrm{~d}^{-1}$ ) include net primary production (i.e. phytoplankton uptake of DFe shown as positive for comparison), total advection, low frequency total advection (computed from two-month running average of $\mathrm{u}, \mathrm{v}, \mathrm{w}$ and DFe), eddy advection (total - low frequency), vertical diffusion, net remineralization and the total DFe tendency $\left(\mathrm{DFe}_{\mathrm{t}}\right.$ ). Vertical profiles for each term averaged in (a) summer (November - February) and (b) winter (July 
(d) a subsurface layer (190 - $300 \mathrm{~m}$, the DFe reservoir). Climatologies of (e) mixed-layer depth and (f) vertical and lateral components of euphotic layer integrated advection.
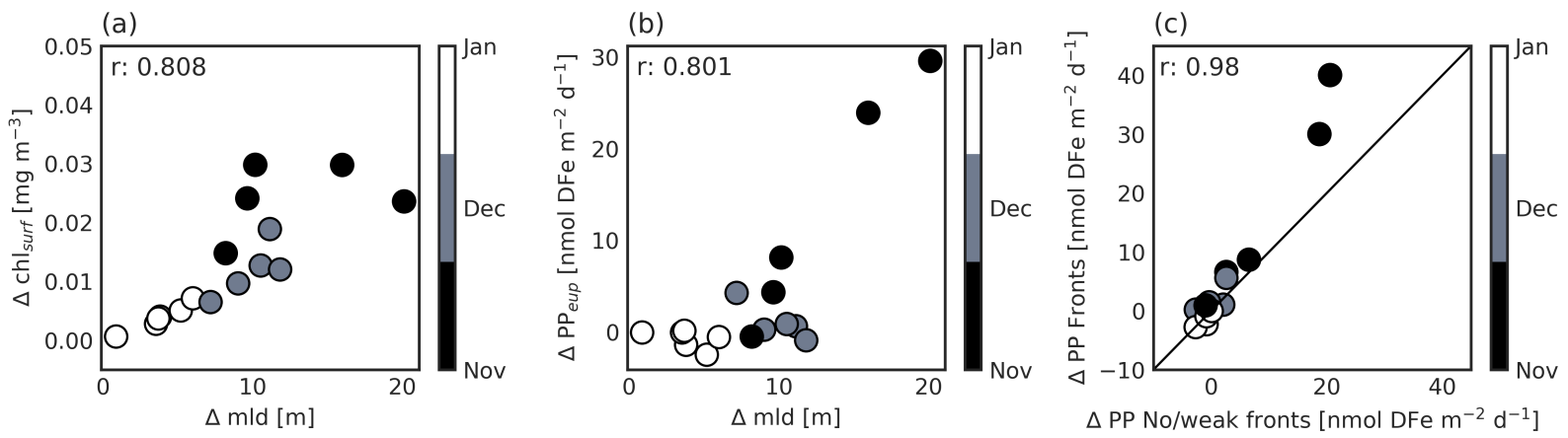

Figure 3: $(a, b)$ The relationship between the storm-driven change ( $\Delta$ : storm - pre-storm) of (a) surface chlorophyll (chl surf $\left._{1} \mathrm{mg} \mathrm{m}^{3}\right)$ and (b) euphotic layer integrated primary production $\left(\Delta \mathrm{PP}_{\text {eup }}\right.$, nmol DFe $\mathrm{m}^{2} \mathrm{~d}^{-1}$ ) against the storm-driven change on the mixed-layer depth ( $\left.\triangle \mathrm{MLD}, \mathrm{m}\right)$, for 16 individual summer storms over 4 consecutive summers. (c) The relationship between $\Delta \mathrm{PP}_{\text {eup }}$ separated spatially into fronts $(\Delta \mathrm{PP}$ fronts) and weak/no fronts $(\Delta \mathrm{PP}$ weak/no fronts). The 1:1 line is marked in black. Fronts are regions with strong $\left(>65^{\text {th }}\right.$ percentile) horizontal gradients in sea surface temperature. In (a) and (b) each point represents the spatially averaged impact of a storm. Pearson correlation coefficient $(r)$ is on each panel.
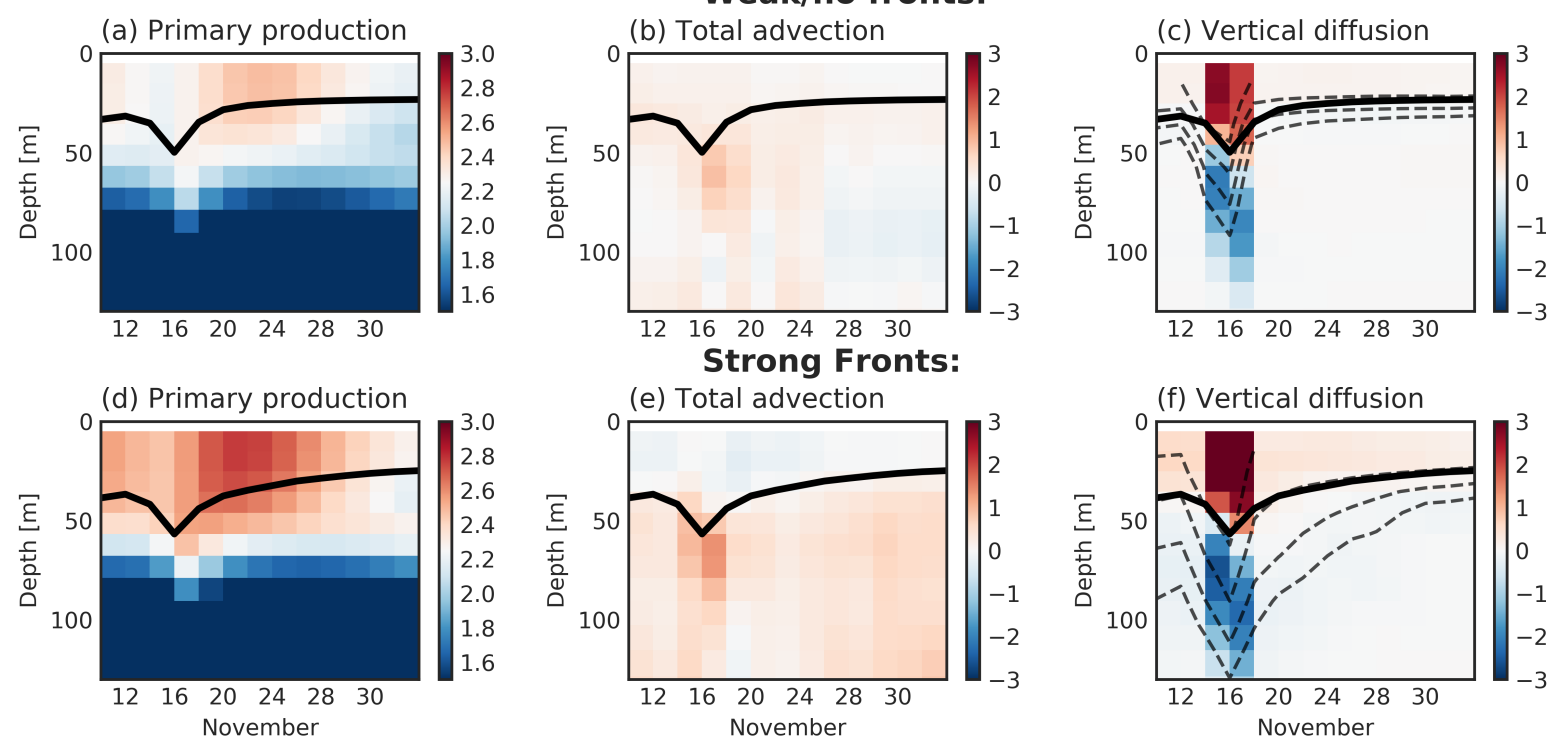

Figure 4: Depth-time composites separated and averaged in regions of weak/no fronts (top) and strong fronts (bottom) showing the storm-driven response of $(\mathrm{a}, \mathrm{d})$ net primary production and iron supply for $(b, e)$ total advection and (c, f) vertical diffusion. Units in nmol DFe $\mathrm{m}^{3} \mathrm{~d}^{-1}$. (c, f) 
dashed-lines are $\log 10\left(\mathrm{k}_{\mathrm{z}}\right)$ at $-7,-6,-5$ and $-4 \mathrm{~m}^{2} \mathrm{~s}^{-1}$. The black line is the mean MLD within fronts and no/weak fronts.

\section{References}

Abernathey, R., Marshall, J., and Ferreira, D. (2011). The Dependence of Southern Ocean Meridional Overturning on Wind Stress. Journal of Physical Oceanography, 41(12), 2261-2278. https://doi.org/10.1175/jpo-d-11-023.1

Ardyna, M., Lacour, L., Sergi, S., d'Ovidio, F., Sallée, J.-B., Rembauville, M., et al. (2019). Hydrothermal vents trigger massive phytoplankton blooms in the Southern Ocean. Nature Communications, 10(1), 2451. https://doi.org/10.1038/s41467-019-09973-6

Arrigo, K. R., van Dijken, G. L., and Bushinsky, S. (2008). Primary production in the Southern Ocean, 1997-2006. Journal of Geophysical Research: Oceans (1978-2012), 113(C8). https://doi.org/10.1029/2007jc004551

Aumont, O., Ethé, C., Tagliabue, A., Bopp, L., and Gehlen, M. (2015). PISCES-v2: an ocean biogeochemical model for carbon and ecosystem studies. Geoscientific Model Development, 8(8), 2465-2513. https://doi.org/10.5194/gmd-8-2465-2015

\section{Boyd, P. W. (2002). ENVIRONMENTAL FACTORS CONTROLLING PHYTOPLANKTON} PROCESSES IN THE SOUTHERN OCEAN1. Journal of Phycology, 38(5), 844-861. https://doi.org/10.1046/j.1529-8817.2002.t01-1-01203.x

Boyd, P., Law, C., Hutchins, D., Abraham, E., Croot, P., Ellwood, M., et al. (2005). FeCycle: Attempting an iron biogeochemical budget from a mesoscale SF6 tracer experiment in unperturbed low iron waters. Global Biogeochemical Cycles, 19(4), 1-13. https://doi.org/10.1029/2005gb002494

Boyd, P., and Ellwood, M. (2010). The biogeochemical cycle of iron in the ocean. Nature Geoscience, 3(10), 675. https://doi.org/10.1038/ngeo964

Boyd, P. W., Ellwood, M. J., Tagliabue, A., and Twining, B. S. (2017). Biotic and abiotic retention, recycling and remineralization of metals in the ocean. Nature Geoscience, 10(3), 167173. https://doi.org/10.1038/ngeo2876

Bowie, A. R., Lannuzel, D., Remenyi, T. A., Wagener, T., Lam, P. J., Boyd, P. W., et al. (2009). Biogeochemical iron budgets of the Southern Ocean south of Australia: Decoupling of iron and nutrient cycles in the subantarctic zone by the summertime supply. Global Biogeochemical Cycles, 23(4). https://doi.org/10.1029/2009gb003500

Callies, J., Ferrari, R., Klymak, J. M., and Gula, J. (2015). Seasonality in submesoscale turbulence. Nature Communications, 6(1), 6862. https://doi.org/10.1038/ncomms7862 
Capet, X., Campos, E., and Paiva, A. (2008). Submesoscale activity over the Argentinian shelf. Geophysical Research Letters, 35(15). https://doi.org/10.1029/2008gl034736

Carranza, M. M., and Gille, S. T. (2015). Southern Ocean wind-driven entrainment enhances satellite chlorophyll-a through the summer. Journal of Geophysical Research: Oceans, 120(1), 304-323. https://doi.org/10.1002/2014jc010203

Fauchereau, N., Tagliabue, A., Bopp, L., and Monteiro, P. M. (2011). The response of phytoplankton biomass to transient mixing events in the Southern Ocean. Geophysical Research Letters, 38(17). https://doi.org/10.1029/2011g1048498

Franks, P. J., and Walstad, L. J. (1997). Phytoplankton patches at fronts: A model of formation and response to wind events. Journal of Marine Research, 55(1), 1-29(29).

https://doi.org/10.1357/0022240973224472

Frenger, I., Münnich, M., Gruber, N., and Knutti, R. (2015). Southern Ocean eddy phenomenology. Journal of Geophysical Research: Oceans, 120(11), 7413-7449. https://doi.org/10.1002/2015jc011047

Giddy, I. S., Swart, S., and Tagliabue, A. (2012). Drivers of non-Redfield nutrient utilization in the Atlantic sector of the Southern Ocean. Geophysical Research Letters, 39(17).

https://doi.org/10.1029/2012g1052454

Graham, R. M., Boer, A. M., van Sebille, E., Kohfeld, K. E., and Schlosser, C. (2015). Inferring source regions and supply mechanisms of iron in the Southern Ocean from satellite chlorophyll data. Deep Sea Research Part I: Oceanographic Research Papers, 104, 9-25. https://doi.org/10.1016/j.dsr.2015.05.007

Jouanno, J., Capet, X., Madec, G., Roullet, G., and Klein, P. (2016). Dissipation of the energy imparted by mid-latitude storms in the Southern Ocean. Ocean Science, 12(3), 743-769. https://doi.org/10.5194/os-12-743-2016

Jickells, T. D., An, Z. S., Andersen, K. K., Baker, A. R., Bergametti, G., Brooks, N., et al. (2005). Global iron connection between desert dust, ocean biogeochemistry, and climate. Science, 308(5718), 67-71. https://doi.org/10.1126/science.1105959

Lévy, Marina, Estublier, A., and Madec, G. (2001). Choice of an advection scheme for biogeochemical models. Geophysical Research Letters, 28(19), 3725-3728. https://doi.org/10.1029/2001g1012947

Lévy, M, Klein, P., and Jelloul, B. M. (2009). New production stimulated by high-frequency winds in a turbulent mesoscale eddy field. Geophysical Research Letters, 36(16). https://doi.org/10.1029/2009g1039490

Lévy, Marina, Franks, P. J., and Smith, S. K. (2018). The role of submesoscale currents in structuring marine ecosystems. Nature Communications, $9(1), 4758$. 
https://doi.org/10.1038/s41467-018-07059-3

Llort, J., Lévy, M., Sallée, J.-B., and Tagliabue, A. (2015). Onset, intensification, and decline of phytoplankton blooms in the Southern Ocean. ICES Journal of Marine Science, 72(6), 19711984. https://doi.org/10.1093/icesjms/fsv053

Llort, J., Lévy, M., Sallée, J.-B. and Tagliabue, A. (2019). Nonmonotonic response of primary production and export to changes in mixed-layer depth in the Southern Ocean. Geophysical Research Letters, 46 (6), 3368-3377.

Madec, G (2008). NEMO ocean engine, Note du Pôle de modélisation, Institut Pierre-Simon Laplace (IPSL), France, No 27, ISSN No 1288-1619

Mahadevan, A., and Tandon, A. (2006). An analysis of mechanisms for submesoscale vertical motion at ocean fronts. Ocean Modelling, 14(3-4), 241-256.

https://doi.org/10.1016/j.ocemod.2006.05.006

Moore, C., Mills, M., Arrigo, K., Berman-Frank, I., Bopp, L., Boyd, P., et al. (2013). Processes and patterns of oceanic nutrient limitation. Nature Geoscience, 6(9), 701.

https://doi.org/10.1038/ngeo1765

Mtshali, T., Horsten, N., Thomalla, S., Ryan-Keogh, T., Nicholson, S. -A., Roychoudhury, A., et al. (2019). Seasonal Depletion of the Dissolved Iron Reservoirs in the Sub-Antarctic Zone of the Southern Atlantic Ocean. Geophysical Research Letters, 46(8), 4386-4395.

https://doi.org/10.1029/2018g1081355

Nicholson, S., Lévy, M., Llort, J., Swart, S., and Monteiro, P. M. (2016). Investigation into the impact of storms on sustaining summer primary productivity in the Sub-Antarctic Ocean. Geophysical Research Letters, 43(17), 9192-9199. https://doi.org/10.1002/2016g1069973

Patoux, J., Yuan, X., and Li, C. (2009). Satellite-based midlatitude cyclone statistics over the Southern Ocean: 1. Scatterometer-derived pressure fields and storm tracking. Journal of Geophysical Research: Atmospheres (1984-2012), 114(D4). https://doi.org/10.1029/2008jd010873

du Plessis, M, Swart, S., Ansorge, I., and Mahadevan, A. (2017). Submesoscale processes promote seasonal restratification in the Subantarctic Ocean. Journal of Geophysical Research: Oceans, 122(4), 2960-2975. https://doi.org/10.1002/2016jc012494

du Plessis, Marcel, Swart, S., Ansorge, I. J., Mahadevan, A., and Thompson, A. F. (2019). Southern Ocean seasonal restratification delayed by submesoscale wind-front interactions. Journal of Physical Oceanography. https://doi.org/10.1175/jpo-d-18-0136.1

Racault, M.-F., Quéré, C., Buitenhuis, E., Sathyendranath, S., and Platt, T. (2012). Phytoplankton phenology in the global ocean. Ecological Indicators, 14(1), 152-163. 
https://doi.org/10.1016/j.ecolind.2011.07.010

Reffray, G., Bourdalle-Badie, R., and Calone, C. (2015). Modelling turbulent vertical mixing sensitivity using a 1-D version of NEMO. Geoscientific Model Development, 8(1), 69-86. https://doi.org/10.5194/gmd-8-69-2015

Rintoul, S., Hughes, C., and Olbers, D.: The Antarctic Circumpo- lar Current System, in: Ocean Circulation and Climate, edited by: Siedler, G., Church, J., and Gould, J., Academic Press, New York, 271-302, 2001.

Rosso, I., Hogg, A., Matear, R., and Strutton, P. G. (2016). Quantifying the influence of submesoscale dynamics on the supply of iron to Southern Ocean phytoplankton blooms. Deep Sea Research Part I: Oceanographic Research Papers, 115, 199-209.

https://doi.org/10.1016/j.dsr.2016.06.009

Ryan-Keogh, T. J., Thomalla, S. J., Mtshali, T. N., van Horsten, N. R., and Little, H. J. (2018). Seasonal development of iron limitation in the sub-Antarctic zone. Biogeosciences, 15(14), 4647-4660. https://doi.org/10.5194/bg-15-4647-2018

Sasaki, H., Klein, P., Qiu, B., and Sasai, Y. (2014). Impact of oceanic-scale interactions on the seasonal modulation of ocean dynamics by the atmosphere. Nature Communications, 5(1), 5636. https://doi.org/10.1038/ncomms6636

Swart, S., Thomalla, S. J., and Monteiro, P. (2015). The seasonal cycle of mixed layer dynamics and phytoplankton biomass in the Sub-Antarctic Zone: A high-resolution glider experiment. Journal of Marine Systems, 147(J. Geophys. Res. 113 2008), 103-115. https://doi.org/10.1016/j.jmarsys.2014.06.002

Tagliabue, Alessandro, Bopp, L., Dutay, J.-C., Bowie, A. R., Chever, F., Jean-Baptiste, P., et al. (2010). Hydrothermal contribution to the oceanic dissolved iron inventory. Nature Geoscience, 3(4), 252. https://doi.org/10.1038/ngeo818

Tagliabue, A., Mtshali, T., Aumont, O., Bowie, A., Klunder, M., Roychoudhury, A., and Swart, S. (2012). A global compilation of dissolved iron measurements: focus on distributions and processes in the Southern Ocean. Biogeosciences, 9(6), 2333-2349. https://doi.org/10.5194/bg-9$\underline{2333-2012}$

Tagliabue, A., Sallée, J.-B., Bowie, A. R., Lévy, M., Swart, S., and Boyd, P. W. (2014). Surfacewater iron supplies in the Southern Ocean sustained by deep winter mixing. Nature Geoscience, 7(4), ngeo2101. https://doi.org/10.1038/ngeo2101

Uchida, T., Balwada, D., Abernathey, R., McKinley, G., Smith, S., \& Levy, M. (2019). The contribution of submesoscale over mesoscale eddy iron transport in the open Southern Ocean. Journal of Advances in Modeling Earth Systems. https://doi.org/10.31223/osf.io/xwb75

Thomalla, S., Fauchereau, N., Swart, S., and Monteiro, P. (2011). Regional scale characteristics 
527 of the seasonal cycle of chlorophyll in the Southern Ocean. Biogeosciences, 8(10), 2849-2866.

528 https://doi.org/10.5194/bg-8-2849-2011

529

530

531

532

533

534

535

536

537

538

539

540

541

542

543

544

545

546

547

548

549

550
Whitt, D., Lévy, M., and Taylor, J. (2017a). Low-frequency and high-frequency oscillatory winds synergistically enhance nutrient entrainment and phytoplankton at fronts. Journal of Geophysical Research: Oceans, 122(2), 1016-1041. https://doi.org/10.1002/2016jc012400

Whitt, D., Taylor, J., and Lévy, M. (2017b). Synoptic-to-planetary scale wind variability enhances phytoplankton biomass at ocean fronts. Journal of Geophysical Research: Oceans, 122(6), 4602-4633. https://doi.org/10.1002/2016jc011899

Yu, L., and Weller, R. A. (2007). Objectively Analyzed Air-Sea Heat Fluxes for the Global IceFree Oceans (1981-2005). Bulletin of the American Meteorological Society, 88(4), 527-539. https://doi.org/10.1175/bams-88-4-527

Yuan, X. (2004). High-wind-speed evaluation in the Southern Ocean. Journal of Geophysical Research: Atmospheres (1984-2012), 109(D13), https://doi.org/10.1029/2003jd004179

Yuan, X., Patoux, J., and Li, C. (2009). Satellite-based midlatitude cyclone statistics over the Southern Ocean: 2. Tracks and surface fluxes. Journal of Geophysical Research: Atmospheres (1984-2012), 114(D4). https://doi.org/10.1029/2008jd010874 